\title{
Study on the Communication of Ideological and Political Education in Colleges and Universities
}

\author{
Yajing Wang \\ School of Information Science and Technology \\ Jinan University \\ Guangzhou, China 510000
}

\begin{abstract}
In modern times, the realization of the great rejuvenation of the Chinese nation is the greatest dream of the Chinese people. Building a strong country in education is a fundamental project for the great rejuvenation of the Chinese nation. Report of the 19th National Congress of the Communist Party of China emphasized priority should be given to the development of education, to accelerate the modernization of education, and to provide education that is satisfactory to the people. To integrate Xi Jinping's socialist ideology with Chinese characteristics into ideological and political education in universities in the new era, and strengthen the sense of innovation in work; strengthen moral education and cultivate people as the fundamental task of school education, and deepen the comprehensive reform of higher education; and use the promotion of world-class universities and the development of first-rate disciplines(After referred to as Double First-rate) construction as a guide for action. Do a good job of socialism education with Chinese characteristics.
\end{abstract}

Keywords-ideological and political education; communication; media literacy; the internet; innovation

\section{INTRODUCTION}

The Nineteenth National Congress of the Communist Party of China clarified the new mission of the Communist Party of China in the new era and opened a new journey for the building of a socialist modernized nation. It should establish Xi Jinping's socialist ideology with Chinese characteristics as the guiding ideology that our party must adhere to for a long time. On December 7 to $8,2017, \mathrm{Xi}$ Jinping emphasized at the National College Ideological and Political Work Conference that our colleges and universities are under the leadership of the party's colleges and universities and Socialism University with Chinese characteristics. To run our universities well, we must adhere to the guidance of Marxism and fully implement the party's education policy [1]. How to develop ideological and political work under the mass media environment is an important topic of the moment. This is of far-reaching significance in advancing the party's ideological work, and is

People's Republic of China Central People's Government Network. On December 7 to 8, 2017, Xi Jinping:Speech at National Conference on Ideological and Political Work

http://www.gov.cn/jrzg/2013-08/20/content 2470777 .htm a prerequisite for achieving a leap-forward development of China from a large country of higher education to a strong country of higher education. It is the fundamental guarantee for strengthening the country's core competitiveness and promoting the country's economic and social development. It is the basis for the overall development of "Double Firstrate".

\section{THE DEVELOPMENT OF IDEOLOGICAL AND POLITICAL EDUCATION IN COLLEGES AND UNIVERSITIES IN THE NEW ERA}

In today's era, information science and technology are developing rapidly. We live in an era full of "data", and it is a diverse, interactive and competitive information and social environment. The development of the Internet has had a tremendous and far-reaching impact on politics, economy, science and technology, and culture. It has particularly affected the spread of ideological and political education in universities. With its characteristics of large scope of dissemination, wide coverage, fast dissemination, and diverse channels of communication, it has brought opportunities and challenges to the innovation of ideological and political education in colleges and universities. As university workers, we must attach importance to the influence of the mass media on the dissemination of ideological and political education, thoroughly implement the strategic layout of the new era, and conscientiously implement the great policy of "Double First-rate" construction.

\section{A. The Internet plus Time Comes}

The China Internet Network Information Center (CNNIC) released the 41st Statistical Report on China's Internet Development in Beijing. The Report shows that as of December 2017, the number of Internet users in China reached 772 million, and the penetration rate reached $55.8 \%$, which was $4.1 \%$ higher than the global average and 9.1 percentage points higher than the average level in Asia[2]. Most contemporary college students were born after the 1990s. They usually have active thinking and are curious and

The website of the State Internet Information Office of the People's Republic of China. CNNIC released the 41st Statistical Report on Internet Development in China http://www.cac.gov.cn/201801/31/c 1122346138.htm 
sensitive to new things. The influence of the media is obvious and far-reaching. In 2013, Xi Jinping pointed out in his important speech at the National Conference on Propaganda and Ideological Work: "Propaganda and ideological work is a life-long job. Where do people focus on? Where do people go? Many people, especially young people, do not basically read the mainstream media. Most of the information all of them are obtained from the Internet. We must face this fact squarely, step up our efforts in investing and grasp the initiative on this battlefield as soon as possible. We cannot be marginalized [3]." The youth is the country's prosperity, and the youth is the countries strong. The younger generation has ideals, skills, and responsibility. The country has a future and the nation has hope [4]. Strengthen and improve undergraduate ideological and political education in the mass media environment, improve young people's ideological and political consciousness, and cultivate socialism with Chinese characteristics the builders and successors of the business are the requirements of the times, the trust of history, and the expectations of the people.

\section{B. To Keep Pace with the Times and Develop Ideological and Political Education Work}

Since the 18th National Congress of the Communist Party of China, the Party Central Committee has attached great importance to network security. General Secretary Xi Jinping has served as the leader of the Central Cyber Security Informationization Leading Group, making important assertions that "no network security is without national security," and puts forward the goal of building an Internet powerhouse. In the new era, Chinese society is undergoing profound changes and trmittee and the State Council issued the Opinions on Strengthening and Improving Ideological and Political Work in Colleges and Universities under the New Situation. The Opinions point out that the Internet is Unprecedented breadth and depth into people's lives, for the ideological and political work in colleges and universities, take the initiative to meet the challenges of the Internet, change the situation, take advantage of the potential, and deepen the implementation of college ideological and political theory curriculum platform. Strengthen the development of the theme web site, study and study software, be good at summing up, make bold breakthroughs, and use the methods that college students are interested in to conduct ideological and political education.

\section{New Paths of Ideological and Political Education in Colleges and Universities}

Xi Jinping pointed out: To do a good job of ideological and political work in colleges and universities must be based on the facts, because of the times, and the new situation. Different media, environments, and factors may affect the new changes and characteristics of the ideas of college students. The continuous development of the Internet

People's Network. Xi Jinping: National Propaganda and Ideological Work Conference

http://politics.people.com.cn/n/2013/0821/c1024-22635998.html

Sohu.com 19th report

http://www.sohu.com/a/199198388_100018708 requires that ideological and political educators in universities continue to pay attention to new situations, new problems, and new situations in the ideological and political activities of college students in the new era, and conduct indepth research on the content and methods of ideological and political education work to improve the quality of ideological and political education in colleges and universities and effects. Therefore, in light of the theory and research results of communication science, we will study ideological and political education across disciplines and across different fields, and in-depth practice to find new carriers, new methods, and new approaches for college students' ideological and political education. Students are really interested in receiving education, actively seek out and contact relevant information content, and can continue to maintain.

\section{THE COMPOSITION OF THE SPREAD OF IDEOLOGICAL AND POLITICAL EDUCATION IN COLLEGES AND \\ UNIVERSITIES UNDER THE MASS MEDIA ENVIRONMENT}

The ideological and political education is that "society or society uses certain ideological, political, and moral concepts, and exerts a purposeful, planned, and organized influence on its members, so that they form a moral character that meets the needs of a certain society or a certain class and Social practice activities [5]." Well-known Chinese communication scholar, Qingguang Guo proposed: The dissemination process is usually made by communicators, Receivers, Messages, Mediaand Feedback. Learning from the theory of communication and realizing the organic combination of communication and the ideological and political education of college students will promote the reform and innovation of the ideas, methods and means of ideological and political education for college students.

\section{A. Communicator}

Generally refers to the originator of the dissemination of information. The communicators in the thought of ideological and political education in colleges and universities include party and government cadres, ideological and political theory teachers, counselors, head teachers, and academic cadres. U.S. social psychologist Kurt Luin proposed the concept of "gatekeeper", which not only applies to news communication theory, but also cannot be ignored in the ideological and political education of college students.

1) The dissemination of content must reflect mainstream ideology and socialist value orientation: Socialism universities with Chinese characteristics are colleges and universities under the leadership of the party. We must adhere to the guidance of Marxist theory, adhere to the direction of socialist education, fully implement the Party's education policy, recognize the road to development, enhance the study of theories, and establish the maintenance system and culture. Edification; resolutely upholds and

\footnotetext{
Zhang Yaocan, Chen Wanbai. Principles of ideological and political education[M]. Beijing: Higher Education Press, 2001:4.
} 
practices the socialist system with Chinese characteristics and socialist modernization. The setting of the agenda of ideological and political education for college students must focus on the overall situation, and must be consistent with the principles and policies of the Party Central Committee on the guiding ideology. Closely centering on the reality of college students' learning and living, we must use dialectical and development perspectives to analyze and solve problems.

2) Yongzheng is guided by public opinion and creates a good educational atmosphere: The real life is rich and colorful, and information is mixed. The ideological and political education media environment is characterized by interactivity, diversity, and occultation. In this open network environment, everyone has a microphone and can post information freely. Party committees at all levels must put ideological and political work in universities in an important position, improve the system, and strengthen management. With the cooperation of party committees and departments, we use effective technical means to filter and monitor educational information in real time, eliminate bad information in a timely manner, restrain and combat deviations from ideological and political education, and standardize network communication order and environment.

3) Do a good job in the processing and selection of information, and choose the information that suits the growth characteristics of the students: The content of the dissemination tends to be rich and immediate. The ideological and political education workers do not transmit the original information received to the students. Instead, they optimize the information and actively explore the new laws, new methods, and new models of party building science. Educational value. This requires ideological and political educators to continuously improve their professional capabilities and levels, strengthen their study and grasp of policy guidelines, analyze specific issues, and do a good job in the education of students, which will play a role in the formation and development of students' ideological and political morality. Infiltration.

\section{B. Receive Units}

Generally refers to the recipient and feedback of the information. In the work of ideological and political education in colleges and universities, the recipients mainly refer to the educated. The dissemination of ideological and political education is actually a kind of social behavioral norms, transformation and sublimation of internal moral qualities. After receiving communication, college students use what they have learned. Knowledge is selectively accepted and understood. Therefore, students' selfrequirements, media literacy, and behavioral habits will all affect the effectiveness of ideological and political education.

1) Pay attention to the needs of college students and increase the value of communication: Xi Jinping pointed out that in order to do a good job of ideological and political work in colleges and universities, students' ideological dynamics should be grasped in real time, students' ideological concerns should be promptly responded to, and students' ideological doubts should be patiently addressed. Students should be encouraged to grow into talents. In the early "magic bomb theory", the audience was only a target, what the media communicated to the audience and what the audience accepted. The dissemination of ideological and political education under the mass media environment is no longer a single preaching style. Online media has equal access for university students and teachers. It follows the students' interests and hobbies, follows the laws of ideological and political work, and fully respects the university student's dominant position. Ideological and political education in colleges and universities has become a two-way interactive process. It enables students to quickly, timely and accurately understand the political, economic and cultural issues that are taking place in various places and meet the needs and expectations of students' growth and development so as to achieve a good educational effect.

2) Improve college students' media literacy and improve the efficiency of communication: The development of the Internet has made the ideological and political communication work open, interactive, and timely, but it also faces many challenges. There is instability and uncontrollability in the psychological development of college students, and the information on the Internet is mixed. There are some "three vulgar" (vulgar, vulgar, vulgar) information and touching the moral and ethical bottom line. These bad information can easily make the mood of university students fluctuate and affect their learning and life. Colleges and universities must adhere to peopleoriented, strengthen media literacy education, learn to analyze and question the ability of media criticism, formulate specific goals and plans, independently think, judge, and screen, master the basic skills of contact with media, and strive to be free, interactive, and complex media. Look for the information you need in your environment.

3) Cultivate the university's good habits and behaviors to achieve the purpose of communication: For college students entering the campus, they will feel uncomfortable in the face of unfamiliar circumstances and crowds, and psychological problems such as inner anxiety and emotional instability will appear more or less. Therefore, ideological and political educators need patience and meticulous psychological counseling and intervention to promptly guide students with psychological problems and help them integrate into college students' lives as soon as possible. Actively participate in understanding ideological and political education activities and develop good ideological morality and behavioral habits. Through the campus media, party building websites, academic lectures, and peer interactions, we can help students solve learning and life problems. Use abundant party building resources to improve the ideological and moral qualities of college students, promote the healthy and comprehensive development of 
college students, and lay a solid foundation for future work and life.

\section{Message}

Generally refers to a number of interrelated symbols that can express a particular message. The content of ideological and political education dissemination should meet the requirements of education tasks and goals, meet different levels and different needs of students, and strive to achieve the scientific, comprehensive and diverse content of ideological and political education.

1) Carry forward the theme of the times and transmit the positive energy of society: Studying and implementing the spirit of the Nineteenth National Congress of the Communist Party is an important task for the university at present and in the period to come. We must implement $\mathrm{Xi}$ Jinping's socialist ideology with Chinese characteristics in the new era. Adhere to the party's main responsibility for the leadership of colleges and universities, and the implementation of the party committee of colleges and universities to fully administer the party in a strict manner, we must insist on the strengthen moral education and cultivate people as the central link, and permeate the whole process of education and teaching through ideological and political work, realize the whole process of educating people and bringing people into full play. Create a new situation for the development of China's higher education[6]. Promptly transfer the party's theory, line, and guidelines to help college students establish a correct political position and direction, strengthen and improve college propaganda and ideological work in the new situation, and firmly grasp the leadership of ideological work in universities[7],correctly guide the moral concepts and behaviors of college students and lay a solid foundation for accelerating the strategy of building world-class universities and first-rate disciplines. Improve the level of development of China's higher education.

2) Theory links reality with the pulse of the times: The party Central Committee attaches great importance to the propaganda work in the ideological field. Through ideological and political education, college students are trained as qualified builders and reliable successors of the socialist cause. The party committees at all levels of the university keep up with the pace of the times, are close to the actual conditions of students, are close to professional requirements, and are close to social life. Through the study of ideological and political theory, we can absorb the latest theoretical research results and apply certain methodologies to study new situations and solve new problems. Party

\footnotetext{
6 People's Republic of China Central People's Government Network. From December 7th to 8th, Xi Jinping: Speech at National Conference on Ideological and Political Work http://www.gov.cn/jrzg/2013-08/20/content_2470777.htm Xinhua NET. October 24, 2015 Coordinated Overall Plan for World-Class Universities and First-Class Disciplines Construction Http://education.news.cn/2015-11/05/c_128396267.htm
}

organizations at all levels, Communist Youth League organizations, party branches, and class organizations have expanded their horizons, increased awareness, and cultivated college students' social practice abilities through the development of Volunteer summer three countryside activities, social research, and campus cultural activities. Guide college students to use the correct world outlook, outlook on life, and value to see some social problems in the process of our country's socialist modernization, to help college students to improve their professional knowledge and ideological and moral cultivation while learning cultural knowledge, and become outstanding talents for the development of moral, intellectual and all-round development.

3) Actively innovate the expression of communication content: Colleges and universities should persist in taking strengthen moral education and cultivate people as the fundamental, continuously strengthen and improve the ideological and political education of college students, and inject fresh blood into the development of ideological and political education. However, the content of ideological and political education is generally more abstract. A single way of preaching cannot enhance persuasiveness. Educators must follow the laws of higher education and the law of student development, keep pace with the times, change educational concepts, and present them in the form of text, pictures, audio, video, 3D animation, etc.Through the application of multimedia, the information data can be converted into some visual language, and the abstraction is specific, and the communication content is expressed concisely and clearly.Stimulate students' interest in learning, and let them actively explore some unknown areas of knowledge.

\section{The Media Is the Transmission Belt of Information Closely Connected with Various Factors in the Process of Transmission}

The popularization of the Internet and the development of self-media completely broke the single media situation in the traditional media era. In the media environment of "the crowds", we can choose different platforms for communication and expand the scope and efficiency of ideological and political education.

1) Organization: Institutions and institutions such as universities and colleges, colleges and universities, school agencies, and societies have a unique and important role in strengthening and innovating ideological and political education in colleges and universities. They focus on personnel training and teaching and scientific research centers, and give full play to the political guarantee and fighting of party organizations. The role of the fortress is to put the party's ideological construction at the forefront, respect the party constitution, and obey the rules of the party as the basic requirements, and guide the teachers and students to conscientiously study Xi Jinping's socialist ideas 
with Chinese characteristics in a new era, transforming the spirit of the 19th National Congress of the Communist Party of China into promoting "Double First-rate". Build a strong driving force and make positive contributions to the development of the school discipline. Activate the school's internal caucus organization, extensively carry out activities such as party and group building, class discussion, social practice, study style lectures, various scientific and technological innovation contests, etc. actively create online and offline interactive mode, and actively understand students' opinions and suggestions on school teaching and management. Under the pioneering model and guidance of party members, do a good job of ideological and political education in colleges and universities.

2) Theme website: Under the new media environment, the theme website is the most direct, convenient, and quick communication platform. Topic websites usually include college ideological and political education thematic websites (Medical Education Network), college party construction, and mission building websites. They mainly serve college students and college students. They support theoretical theories of socialism with Chinese characteristics, and are the study and research of colleges and universities. Promote the learning positions of Marxism-Leninism, Mao Zedong Thought, Deng Xiaoping Theory and the important thinking of the 'Three Represents,' the scientific concept of development, the report of the Nineteenth Congress, and $\mathrm{Xi}$ Jinping's important speech. It is an important platform for carrying forward the main melody, strengthening and improving the ideological and political education of college students, and is an important way to promote the theoretical knowledge of university students. Therefore, we should respect students and care about students and use information technology as a means to open up the columns that college students love. We have a novel website, appropriate content, and lively web pages. We constantly increase its attractiveness and effectiveness, and guide online public opinion so that it becomes The important carrier for carrying out ideological and political education in colleges and universities.

3) Mobile phone media: With the popularization of digital products such as mobile phones and DV, the Internet usage rate of young people continues to rise. Mobile phones have become the main online tools for young people. Promoting the integration of ideological and political education work with information technology, using QQ or WeChat, Weibo and other social media not only frees up students' learning pressure, but also expands the time and space boundaries of communication, improves the speed and efficiency of information dissemination, and greatly facilitates the division of teachers. Students communicate ideas anytime, anywhere. Compared with traditional media, mobile media communication avoids face-to-face direct contact and allows both parties to have sufficient time to think deeply and make communication smoother. For example, the Communist Youth League Committee, the College WeChat public account, the party branches of various agencies, faculty members, and students and other party branches of the QQ group have enshrined the nineteen major learning topics, micro-party classes, micro-typical topics, and micro-sharing through the "Study on the 19th National Congress of the Communist Party of China" topics. interactive tests and other columns, conscientiously implement the important spiritual requirements of the Party Central Committee and higher levels of party committees, carry out the party's mass line education practice activities and "Three Stricts and Three Steadies" special education, strengthen the "party building studies", and strengthen the party members Comrade's ideals and beliefs.

\section{E. Feedback}

It generally refers to relying on feedback adjustment links collected from the outside world and their own evaluation of receiving activities, forming feedback, and adjust their acceptance based on feedback[ 8 ]. Attach importance to the feedback function of ideological and political education in colleges and universities, can timely grasp the effects of ideological and political education, and constantly improve the content, methods and means of ideological and political education to make it more suitable for the development of college students, reflecting the twoway interaction of ideological and political education and university students' main position in the education process.

1) With the aid of the new media network platform, students are encouraged to participate in information feedback through multiple channels and multiple means: It should pay close attention to the dynamics of college students, grasp the ideas of college students, and actively explore the new laws, new systems, new methods, and new models of ideological and political education. Through the interactive process of education, students' main role is played, and the development of a democratic and equal educational model is promoted to impart mutual respect and candid exchanges. It not only builds a platform for learning and communication between teachers and students, but also integrates the ideas of college students to the main theme of socialism.

2) Receive student feedback on information, education methods etc. and adjust the dissemination process in a timely manner: By verifying, analyzing, screening, and discriminating the feedback content, the feedback information is reflected to relevant departments. Actively supplement and update the information and materials disseminated in ideological and political education, strengthen the authority and credibility of communication, improve and optimize the methods of communication, and ensure the coordinated development of ideological and

\footnotetext{
8 Lei Zhang. Propagation theory and effective acceptance of college students' ideological and political education [M]. Hangzhou: Zhejiang University Press, 2015: 145.
} 
political education in the right direction so as to improve the effectiveness of ideological and political education purpose.

\section{CONCLUSION}

In the new era, new mission and new mission, we must consciously implement the socialist ideology with Chinese characteristics in the new era of Jinping. We should follow the example of morality, moral education, moral teaching, ideological and political work in colleges and universities, and pay attention to college students' moral education. Combining the theory and research results of communication science, we have achieved new breakthroughs and new explorations in the spread of ideological and political education across disciplines and across fields. Vigorously develop "Double First-rate" construction, constantly improve and improve the governance system and governance capacity of higher education, lay a solid foundation for ideological education, teaching and scientific research, personnel training, and cultural heritage of higher education institutions, in order to strengthen China's education development level and enhance national core competitiveness. To lay a solid foundation for development, and to provide a strong guarantee for achieving the two centenary goals[9] struggle and the Chinese dream of the great rejuvenation of the Chinese nation.

\section{REFERENCES}

[1] Zhang Lei. Communication theory and effective acceptance of college students' ideological and political education [M]. Hangzhou: Zhejiang University Press, 2015:16.

[2] Zhang Yaocan, Chen Wanbai. Principles of Ideological and Political Education[M]. Beijing: Higher Education Press, 2001: 4.

[3] Ji Haiju. Deconstruction and Reconstruction of Ideological and Political Education in Colleges and Universities in the New Media Age [M]. Southeast University Press. 2014

[4] Song Zhenchao. Research on the Effectiveness of Ideological and Political Education in Colleges and Universities from the Perspective of Informationization[M]. Chinese Book Publishing House.2015

[5] Chen Long. Introduction to Mass Communication [M]. Suzhou University Press, 2013.

[6] Guo Qingguang. Communication Course (Second Edition) [M]. Beijing: China Renmin University Press, 2011.

[7] Ouyang Lin. Ideological and political education communication [M]. Beijing: Beijing Jiaotong University Press. 2005.

[8] Shao Peiren. Introduction to Communication Studies [M]. Hangzhou: Zhejiang University Press, 1997.

[9] Hong Tao. Research on the ideological and political education embedded in the network of colleges and universities in the agenda of the new media era [M]. Beijing: Guangming Daily Press. 2016.

[10] Li Linying, Guo Liping. Research on the Teaching of Ideological and Political Education in Colleges and Universities under the New Media Environment [M]. Beijing People's Publishing House, 2015.

[11] Chen Yongzheng. "Two-class" Construction Guided by Socialism with Chinese Characteristics in the New Era of Xi Jinping [J]. Journal of National Institute of Education Administration, 2017, (11).

9 to double the 2010 GDP and per capita income of the Chinese and complete the building of a moderately prosperous society by 2020 and to build a prosperous, strong, democratic, culturally advanced and harmonious modern socialist country and realize the great renewal of the Chinese nation by the middle of the century.
[12] Shi Xiangjun, Xia Yuhan. Strengthening the ideological and political education of the times [J]. Ideological and theoretical education, 2017 (12).

[13] Zheng Yongting. Reflections on the Whole Process of Ideological and Political Work in Colleges and Universities through the Whole Process of Studying and Teaching_-Study of General Secretary Xi Jinping's Speech at the National College Ideological and Political Work Conference [J]. Ideological and Theoretical Education, 2017, (1).

[14] Wu Huaiyou. The Action Plan for Ideological and Political Work in Colleges and Universities in the New Situation: Studying Xi Jinping's Speech at the National Conference on Ideological and Political Work in Colleges and Universities [J]. Mao Zedong Studies, 2017, (2).

[15] Shi Yuchang. Innovative Thinking of Party Construction in Colleges and Universities under the Background of Internet Plus[J]. Journal of Huanggang Normal University, 2016, (2).

[16] Zhu Jidong. Existing problems in the ideological and political work of colleges and universities in the new era and their countermeasures_Learning the spirit of Xi Jinping's important speech at the conference for ideological and political work in colleges and universities across China [J]. Party Politics Research, 2017, (2).

[17] Ren Yanni. Research on the effectiveness of college students' ideological and political education in mass media environment[D]. $\mathrm{PhD}$ thesis, Northwestern Polytechnical University, 2015, (11).

[18] $\mathrm{Hu}$ Bo. Study on the media environment of ideological and political education in universities [D]. Master thesis of East China Normal University, 2009, (5).

[19] Li Xiuqin. Research on the Carrier of Ideological and Political Education in Colleges and Universities[D]. Master thesis of Shandong Normal University, 2008,(5).

[20] Fu Yana. Adolescent ideological and political education hit media environment research [D]. Southwest University of Political Science master's degree thesis, 2010, (3). 